\title{
Cognitive styles in methodology of Russian as a foreign language
}

\author{
Irina Borisovna Avdeyeva ${ }^{1 *}$ and Nadezhda Vladimirovna Krasnokutskaya ${ }^{2}$ \\ ${ }^{1}$ Moscow Automobile and Road Construction State Technical University (MADI), Preparatory \\ Faculty for Foreign Students, Russian Language for Foreigners Department, Moscow, Russia \\ ${ }^{2}$ Moscow State University of Technology “STANKIN", Department of Foreign Languages, Moscow, \\ Russia
}

\begin{abstract}
This article attempts to consider the types of cognitive activity of students in the process of learning foreign languages, including Russian as a foreign language. It contains a synthesis on this topic and practical results of the material implementation developed with the consideration of linguo-cognitive styles of students. Special attention is paid to the analytical cognitive style that is inherent in the students of technical fields. Considering the features of the linguo-cognitive picture of students with a predominantly analytical cognitive style, the authors conclude that these features are innate to the students from European countries who speak European languages and studied within the European educational system. Attention is paid to the consideration of cognitive styles in the existing training materials on RFL. The textbook, created by a group of authors (editor-in-chief Avdeyeva), which is addressed to students of the engineering field, was given as an example. Moreover, the article analyses the special course by Krasnokutskaya, developed at the Pushkin State Russian Language Institute and addressed to European students studying Russian as a foreign language. Based on the analysis and testing of mentioned training materials, conclusions on the feasibility of further development of such manuals are drawn.

Keywords: Russian as foreign language, theory of cognitive styles, analytical left-hemisphere cognitive style, engineering mentality, European mentality
\end{abstract}

\section{Introduction}

The pandemic exacerbated a number of problems in linguodidactics which used to be of low priority during live-time interaction between the teacher and students in the classroom. Certainly, among them are the styles of cognitive activity in teaching foreign languages that are based on the theory of cognitive styles. Changed learning conditions revealed a lot of hidden difficulties that are caused by the differences of students' cognitive activity methods. The theory of cognitive styles has earned unconditional recognition in the scientific world [1-6]. However recently the interest of methodologists is focused to a

*Corresponding author: i.b.avdeveva@mail.ru 
greater extent on other aspects of the learning process: communication, gaming technologies, the use of Internet resources. It is worth to note the following paradox: despite the pronounced trend in modern foreign languages teaching towards individualization of learning, taking into account the interests and needs of the student and maximum "flexibility", modularity of educational materials, such a significant educational component as differences in the types of cognitive activity keeps a low profile. Undoubtedly, there are works devoted to the problems of cognitive styles in foreign languages teaching [7-13], but unfortunately there are very few of them in the field of teaching Russian language as a foreign language [14, 15]. The purpose of the following article is approbation results of developed teaching materials in the classroom, created within the framework of the students' cognitive styles.

\section{Methods}

To meet the goal of the research, methods of scientific literature analysis, generalization of scientific research results, scientific observation and generalization of pedagogical experience were used. A universities-based (Moscow Automobile and Road Construction State Technical University and Pushkin State Russian Language Institute) experimental learning was organized. Two experimental groups (hereinafter E1 and E2) and two control groups (hereinafter $\mathrm{C} 1$ and $\mathrm{C} 2$ ) participated in the experiment. The audience of the groups $\mathrm{E} 1$ and $\mathrm{C} 1$ was represented by engineering students that is future engineers of the Preparatory Faculty for Foreign Citizens of Moscow Automobile and Road Construction State Technical University in the amount of 18 people. This audience was characterized by not yet formed, emerging features of the analytical cognitive style since they are beginners (level A0-B1). Groups E2 and C2 included students-trainees of the Pushkin State Russian Language Institute. This audience is represented by students from European countries who speak Russian at the B1 level.

\section{$3 \quad$ Results}

The first experiment. To overcome the challenges in teaching students of engineering faculties of Russian universities at the Russian language for foreign citizens department of the Moscow Automobile and Road Construction State Technical University (MADI) a training package "Russian for foreign students of engineering" which belongs to the level B1-B2 was created [16]. Training package material takes into account the strengths and weaknesses of students with a dominant left hemisphere and recommends compensatory strategies for the development of those forms of cognitive activity that do not have a characteristic of the analytical cognitive style. The materials and features of the manual from the point of consideration students' cognitive styles were developed in more detail in the work [17], as well as in the preface to the "Book for Teacher" of the manual [18].

To prove the effectiveness of this method also for Beginners experimental learning at the Preparatory Faculty of MADI was held. The experimental group (E1) and control group (C1) represented by engineering students (level A0-B1) participated in the experiment. The groups were formed by students from Afghanistan (2), China (3), Vietnam (4), Zimbabwe (4), Iraq (2) and Syria (3). Prior to the training students of both groups took a diagnostic test which showed a fairly similar level of knowledge in the experimental and control groups (10\% and $20 \%$, respectively). During the training which lasted 10 months, the students of the experimental group were trained according to a specially developed method for 
representatives of the analytical cognitive style, while the students of the control group were trained according to methods-mixed training materials without taking into account their cognitive style. At the end of the experimental learning students of both groups took a test consisting of 100 questions. The average result in the experimental group was (91\%) correct answers, while in the control group it was only $(50 \%)$. Thus, teaching students starting their education at engineering schools according to a certain method proved to be effective.

The second experiment. A special course aimed at preventing interlingual interference at the lexical level and addressed to European students (level B1) was used as training material. The principles of material presentation and methodological practices fully comply with the analytical cognitive style.

The originally developed special course was tested at the Pushkin State Russian Language Institute in 2016-2017 [19]. However, the experiment was held in mixed groups of students, among them were both representatives of European countries and students from India, Thailand, the USA, Tunisia, Japan and Korea, who were proficient in a European language. It was necessary to verify the effectiveness of created training materials in the case of teaching students from European countries (Great Britain, Germany, France, Italy and Spain). An additional experiment was held in 2020, in which the experimental (E2) and control (C2) groups participated. Both groups consisted of 15 European students (3 British, 2 Germans, 9 French, 11 Italians, 5 Spaniards in total). The experimental group used special course material formed according to a certain algorithm, while the control group was educated in the traditional way.

Prior to the experimental learning, both groups took a diagnostic test. The results of the experimental and control groups were approximately the same: $36 \%$ of correct answers in the experimental group and $42 \%$ in the control group. Upon completion of the learning, the students of both groups took a 50 questions test covering the vocabulary of the special course. The results of the experiment proved the effectiveness of the training once again: the average indicators of correct answers in the experimental group were almost two times higher (40 correct answers $-80 \%$ ) than in the control group ( 22 correct answers $-44 \%)$. It was concluded that it is appropriate to use the materials of the certain method in an audience entirely consisting of European students.

Thus, the results of the E1 and E2 groups exceeded the results of the $\mathrm{C} 1$ and $\mathrm{C} 2$ groups, despite the fact that at the beginning the level of knowledge in the experimental and control groups was quite the same. The following data prove once again that used methods and techniques used are effective, and the further development of such materials is a promising direction in teaching Russian as a foreign language (see Figure 1).

\section{Discussion}

Let us recall that the process of learning a foreign language is different among the students. These two different types of perception, storage and processing of educational information in the theory of cognitive styles are conventionally divided into two opposite ends: synthetic cognitive style, with a dominant right hemisphere, and analytical cognitive style, with a dominant left hemisphere. The analytical cognitive style, poorly studied in Russian linguodidactics, was studied in detail in the following works [1-3, 20]. Students with analytical cognitive style choose independent, autonomous forms of work, prefer consistent and limited flow of new information, they are into details and guided by instructions and rules rather than context. It has been proven that these and other features of this style are inherent in foreign engineering students which is reflected in the linguo-cognitive picture of 
this type of students [2]. Special attention should be paid to the fact that engineers (undergraduates, graduate students, trainees) and future engineers encounter a completely different type of cognitive activity during Russian as a foreign language classes in Russian universities - a synthetic cognitive style, which generally is inherent in their Russian teachers. The collision of two completely different cognitive, thinking, and learning styles in the learning process certainly affects the processing of new information and, consequently, student performance [20].

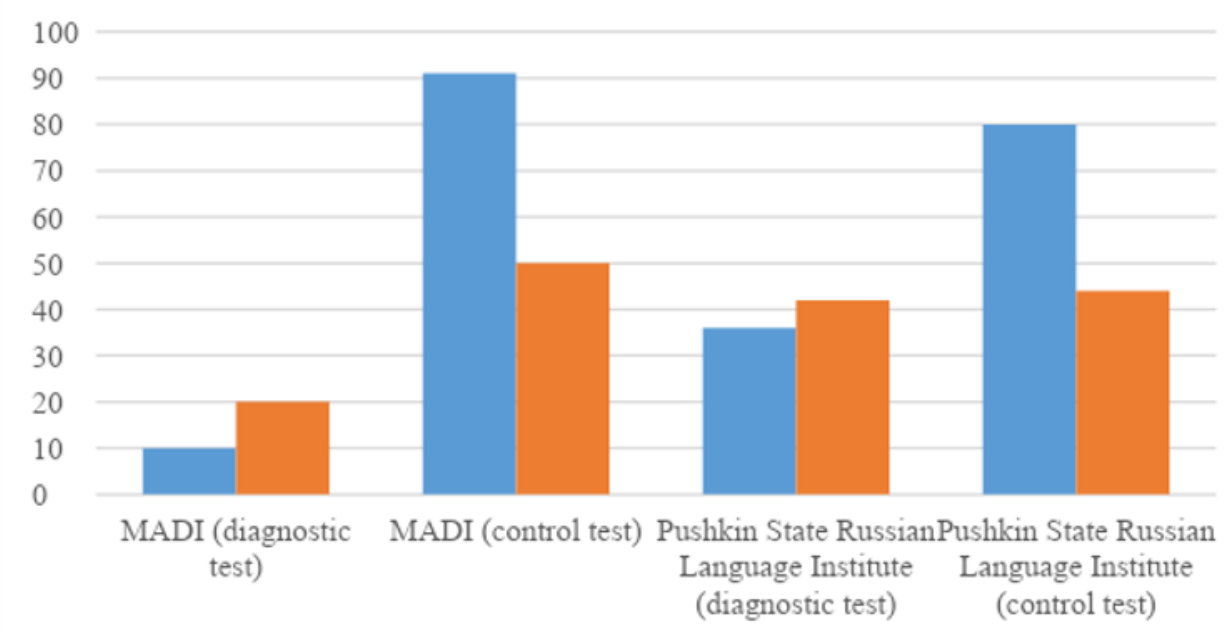

Experimental group $\quad$ Control group

Fig. 1. The results of experimental learning.

However, left-hemispheric thinking and preference for analytical forms of work are typical not only for students of technical fields. The analytical cognitive style, as well as its inherent techniques, technologies and teaching strategies, are preferred by students from European countries. "The entire current educational system of the modern times within the framework of European culture is based on the idea of rationality, logical and formal systems and contributed to the establishment of this particular cognitive general style" [17]. Experience has shown that the types and forms of educational work based on an analytical, left-hemispheric way of thinking are acceptable even for those European students who naturally gravitate towards the synthetic cognitive style but during their studies were influenced by the European analytical educational system.

Conversely, the Russian educational system in general, especially in humanities, gravitates towards the synthetic cognitive style, and the traditions of Russian education involve the use of methods and techniques focused on the synthetic cognitive style [21]. The predominance of the right-hemisphere view of the studied subjects and phenomena are the fundamental features of Russian science. These features also prevail in the methodology of teaching Russian as a foreign language. The way of presenting new material and its organization, tasks, task texts, and the structure of the lesson itself are often influenced by the synthetic cognitive style inherent in both the Russian teacher and the Russian scientific worldview in general $[2,3,22]$. 


\section{Conclusion}

The problem of considering cognitive styles from the point of teaching foreign languages certainly deserves a more detailed research and expansion of the studied groups of students. In our opinion, teaching Russian as a foreign language to students with a predominantly analytical cognitive style, in particular Europeans and students of engineering and technical universities, requires the development of special training materials that takes into account the cognitive features of students from these groups. Cognitive preferences of students and the development of new educational and methodological materials are current tasks of teaching Russian as a foreign language.

\section{References}

1. I.B. Avdeyeva, Sci Bul Voronezh State Univ Archit Civil Eng. Ling Intercult Comm, 2(21),142-150 (2016)

2. I.B. Avdeyeva, World Rus Word, 4, 86-95 (2020). https://doi.org/10.24411/1811-1629-2020-14086

3. I.B. Avdeyeva, World Rus Word, 3, 18-28 (2020). https://doi.org/10.24411/1811-1629-2020-13016

4. V.V. Popova, Vector Sci TSU. Ser: Pedag, Psy, 3(30), 14-19, (2017). https://doi.org/10.18323/2221-5662-2017-3-14-1

5. B.L. Leaver, The next paradigm shift and its historical context, in Transformative Language Learning and Teaching, 13-22 (Cambridge UP, Cambridge, 2021). doi.org/10.1017/9781108870788

6. B.L. Leaver, C. Campbell, The shifting paradigm in Russian language pedagogy, in Communicative language teaching to transformative language learning and teaching. The Art of Teaching Russian, 147-162 (Georgetown UP, Georgetown, 2020). https://doi.org/10.2307/j.ctv18sqxnd

7. I. Aggarwal, et al., Front Psychol, 10, 112 (2019). https://doi.org/10.3389/fpsyg.2019.00112

8. Z. Chen, S. Chen, C. Chien, Edu Tech Soc, 20(4), 69-77 (2017)

9. S. Damart, S. Adam-Ledunois, Impact of cognitive style on group decision and negotiation, in Handbook of Group Decision and Negotiation, 193-210 (Cham, Springer, 2021). https://doi.org/10.1007/978-3-030-49629-6_52

10. T. Höffler, M. Koć-Januchta, D. Leutner, App Cogn Psy, 31(1), 109-115 (2017). https://doi.org/10.1002/acp.3300

11. M. Koć-Januchta, et al., Compn Human Behav, 68, 170-179 (2017). https://doi.org/10.1016/j.chb.2016.11.028

12. R. Nappo, et al., Experim Brain Res, 237, 755-768 (2019). https://doi.org/10.1007/s00221-018-5457-2

13. T. Tambi, F. Murtadho, Z. Rafli, Learning strategy and cognitive style: the effect on students' writing ability, in Proc. First International Conference on Advances in Education, Humanities, and Language. ICEL 2019, 43-48, Malang, Indonesia, 23-24 March 2019 (2019). https://dx.doi.org/10.4108/eai.23-3-2019.2284998 
14. M.M. Syrova, Baltic Human J, 10(1(34)), 270-273 (2021).

https://doi.org/10.26140/bgz3-2021-1001-0062

15. T.A. Khramchenko, Prob Pedag, 1(46), 113-116 (2020)

16. I.B. Avdeyeva, et al., Russkii yazyk dlya inostrannykh studentov-inzhenerov: leksika i grammatika [Russian for foreign engineering students: vocabulary and grammar], I.B. Avdeyeva (ed) (Zlatoust, St. Petrsburg, 2014)

17. I.B. Avdeyeva, Uchebno-metodicheskii kompleks po grammatike russkogo yazyka (uroven B1-B2) [Teaching package of the grammar of the Russian language (level B1-B2)], in Mezhdunarodnoe obrazovanie i sotrudnichestvo, 4-9 (Moscow, 2013)

18. I.B. Avdeyeva, et al., Russkii yazyk dlya inostrannykh studentov inzhenernykh spetsialnostei: leksika i grammatika [Russian for foreign students of engineering: vocabulary and grammar], in 4 parts, I.B. Avdeyeva (ed) (Zlatoust, St. Petersburg, 2019)

19. N.V. Krasnokutskaya, Izuchenie zaimstvovannoi leksiki v russkom yazyke kak lingvodidakticheskaya zadacha (na osnove spetsialnogo kursa dlya inostrannykh studentov [Learning borrowed vocabulary in Russian as a linguodidactic problem (based on a special course for foreign students)], Ph.D. Thesis in Education (Moscow, 2020)

20. Avdeyeva, I.B. Bul Peoples' Friendship Univ Rus. Ser: Iss Edu: Lang Fields, 3, 81-87 (2014)

21. N.V. Krasnokutskaya, Int Postgrad Bul: Rus Lang Abroad, 1, 39-43 (2014)

22. N.V. Krasnokutskaya, World Sci. Pegag Psy, 6(1) (2018) 